\title{
Quantitative histological study of enteropathy associated with HIV infection
}

\author{
A G Cummins, J T LaBrooy, D P Stanley, R Rowland, D J C Shearman
}

\begin{abstract}
A quantitative histological study was performed on small intestinal biopsies from eight ambulatory patients with HIV infection (AIDS/AIDS-related complex, ARC) and compared with those from 16 normal subjects. Enteropathy was assessed by measurement of villus area, crypt length and mitotic count, as well as duodenal counts of intraepithelial lymphocytes, mucosal mast cells and goblet cells. Enteropathy in subjects with AIDS/ARC was shown by reduced mean villus area of 0.363 (SD 0.081) compared with 0.500 (SD $0.064) \mathrm{mm}^{2}$ in control subjects $(p<0.0001)$, while intestinal crypts were of similar length with 239 (SD 36) compared with 225 (SD 28 $\mu \mathrm{m}$, but mitotic count was increased to 3.8 (SD $1.2)$ compared with $2.4(S D 0.8)(p=0.01)$ in the same control subjects. These results indicate villous atrophy with impaired crypt hyperplasia. Duodenal cell counts showed similar numbers of mucosal mast cells, intraepithelial lymphocytes and goblet cells in AIDS/ARC patients and fifteen control subjects.
\end{abstract}

Gastrointestinal symptoms are a common feature and diarrhoea a common management problem in patients infected with the human immunodeficiency virus (HIV). ${ }^{12}$ In a proportion of patients, an infective cause due to common or exotic organisms is found, ${ }^{1-4}$ while there is also evidence for an enteropathy associated with HIV infection. ${ }^{125}$ Enteropathy associated with graftversus-host reaction (GvHR) in animals and coeliac disease in man are believed to be mediated by activated mucosal $T$ lymphocytes which lead to villous atrophy and crypt hyperplasia. ${ }^{67}$ Because of immunodeficiency, this mechanism would be impaired in the enteropathy of HIV infection. Thus, it is important to define quantitatively the exact pattern of enteropathy of HIV infection and, in particular, whether there is crypt hyperplasia. Similarly, increases in intraepithelial lymphocytes, ${ }^{8}$ mucosal mast cells, ${ }^{9}$ and goblet cells ${ }^{10}{ }^{11}$ are associated with $\mathrm{T}$ cell mediation, but one study has found that mucosal mast cells were deficient in AIDS. ${ }^{12}$ The aim of this study is to apply quantitative histölogical techniques to assess enteropathy and the number of duodenal mucosal mast cells, intraepithelial lymphocyte and goblet cells in patients with HIV infection and resulting AIDS or AIDS-related complex (ARC).

\section{Methods}

SUBJECTS

AIDS or ARC was diagnosed in eight patients by antibody to HIV as determined by an enzyme linked immunosorbent assay which was confirmed by Western blotting, by depletion of CD4 peripheral blood lymphocytes, and by clinical features (Table I). Seven of eight subjects received zidovudine (AZT) at the time of the Departments of Medicine
and Infectious Diseases, University of Adelaide and Royal Adelaide Hospital, and the Department of Tissue Pathology, Institute of Medical and Veterinary Science, Adelaide, Australia

A G Cummins,

J T LaBrooy,

D P Stanley,

$R$ Rowland

D J C Shearman

Correspondence to:

Dr A G Cummins,

Department of

Gastroenterology, The Queen Elizabeth Hospital, Woodville Road, Woodville, Adelaide SA 5011, Australia
TABLE I Clinical features of the eight patients with AIDS or ARC

\begin{tabular}{|c|c|c|c|c|}
\hline $\begin{array}{l}\text { HIV subject } \\
\text { Age }(y) / \text { sex }\end{array}$ & & $\underset{(/ \mu l)}{C D 4 \dagger}$ & $C D 4 / C D 8++$ & $\begin{array}{l}\text { Body weight } \\
(\mathrm{kg})\end{array}$ \\
\hline $1^{\star}$ & $\begin{array}{l}\text { Oral candidiasis } \\
\text { Hairy leukoplakia }\end{array}$ & 43 & 0.05 & $68 \cdot 0$ \\
\hline 2 & $\begin{array}{l}\text { Oral candidiasis } \\
\text { Herpes simplex of buttocks (treated) } \\
\text { Kaposi's sarcoma of oesophagus and stomach }\end{array}$ & 99 & 0.30 & $64 \cdot 5$ \\
\hline $\begin{array}{l}3 \\
35 M\end{array}$ & $\begin{array}{l}\text { Oral candidiasis } \\
\text { Weight loss } \\
\text { Diarrhoea (repeated Isospora belli infection) }\end{array}$ & 108 & $0 \cdot 21$ & $52 \cdot 4$ \\
\hline $\begin{array}{l}4 \\
28 M\end{array}$ & $\begin{array}{l}\text { Oral and oesophageal candidiasis } \\
\text { Cerebral toxoplasmosis with transverse myelopathy (treated) } \\
\text { Diarrhoea while on antibiotics } \\
\text { Hepatitis B surface antibody positive }\end{array}$ & 41 & 0.05 & $70 \cdot 4$ \\
\hline $\begin{array}{l}5 \\
38 M\end{array}$ & $\begin{array}{l}\text { Oral candidiasis } \\
\text { Weight loss } \\
\text { Pneumocystitis carini infection (treated) } \\
\text { Kaposi's sarcoma of skin } \\
\text { Hepatitis B surface antibody positive }\end{array}$ & 21 & 0.02 & $54 \cdot 0$ \\
\hline $\begin{array}{l}6^{\star} \\
38 \mathrm{M}\end{array}$ & $\begin{array}{l}\text { Oral and oesophageal candidiasis } \\
\text { Lethargy }\end{array}$ & 35 & 0.36 & $65 \cdot 0$ \\
\hline $74 M$ & $\begin{array}{l}\text { Weight loss } \\
\text { Diarrhoea due to Cryptosporidium (treated) } \\
\text { Cholestatic syndrome (normal ERCP) }\end{array}$ & 126 & 0.66 & $59 \cdot 8$ \\
\hline $\begin{array}{l}8^{\star} \\
32 M\end{array}$ & $\begin{array}{l}\text { Oral and oesophageal candidiasis } \\
\text { Weight loss } \\
\text { Herpex simplex of buttocks (treated) } \\
\text { Diarrhoea }\end{array}$ & 15 & 0.26 & $57 \cdot 0$ \\
\hline
\end{tabular}

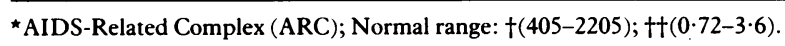



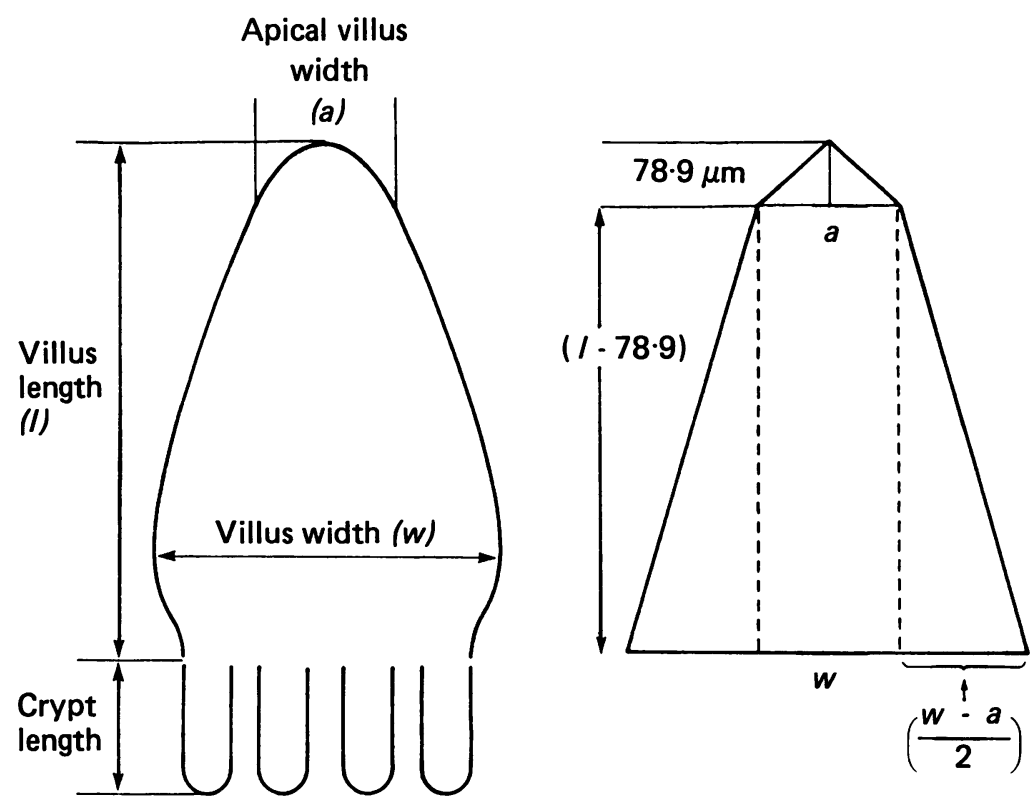

Figure 1: Calculation of villus area from measures of villus length, and apical and basal widths. study. For the eight subjects, the routes of HIV infection were heterosexual (one) or homosexual (seven). Two additional subjects were HIV antibody positive but had no clinical features of AIDS/ARC. Laboratory investigations were done regularly as part of medical management

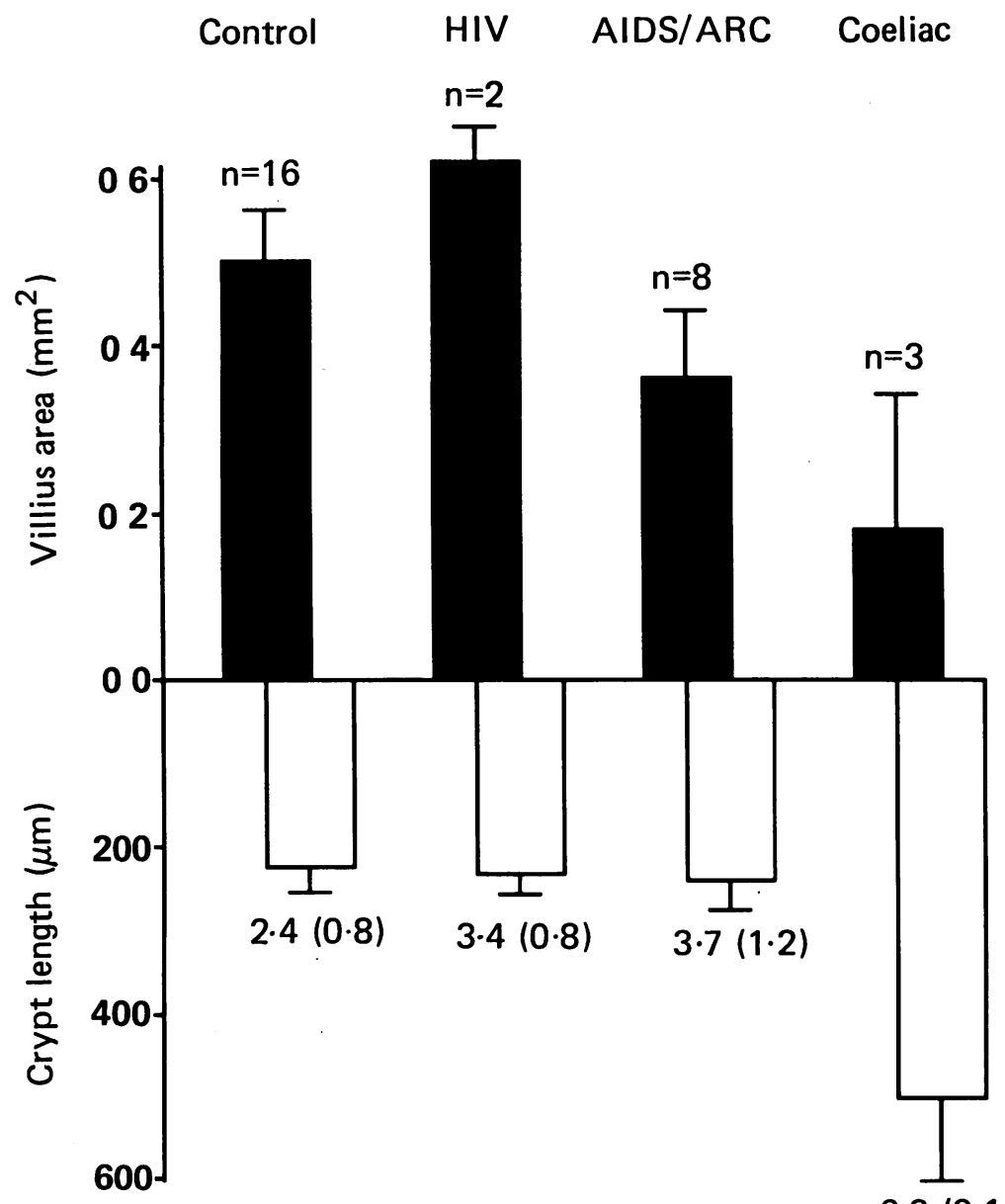

$6.9(0.1)$

Figure 2: Villus area, crypt length and mitotic count of small intestinal biopsies from patients with AIDS/ARC, HIV infection, coeliac disease before treatment, and normal subjects.

of these patients including enumeration of CD4 lymphocytes and $\mathrm{CD} 4 / \mathrm{CD} 8$ ratio values in peripheral blood by flow cytometry. These values were recorded at investigations done within six weeks of intestinal biopsy. Another 16 'normal' subjects undergoing endoscopy whose biopsy and other investigations were later confirmed to be normal were used as control subjects. Three further subjects undergoing routine investigation for coeliac disease had additional biopsies taken for this study and these were used as examples of hyperplastic villous atrophy. Coeliac disease was confirmed in three subjects by clinical improvement, by decreased intestinal permeability on serial testing, and by improved intestinal morphology of a second biopsy while on a gluten free diet. Informed consent was obtained for endoscopy from each patient and the protocol for this study was approved by the Human Ethics Committee of the Royal Adelaide Hospital.

SMALL INTESTINAL BIOPSY

Four small intestinal biopsies were taken at endoscopy from the distal second part of the duodenum. These biopsies were orientated on cardboard before two were placed in Clark's fixative (75\% ethanol: $25 \%$ acetic acid, v/v) and briefly shaken to remove mucus for later microdissection, while the other two biopsies were fixed in Carnoy's fixative (60\% ethanol: $30 \%$ chloroform: $10 \%$ acetic acid, $v / v$ ) for duodenal cell counts.

MEASUREMENT OF VILLUS AREA, CRYPT LENGTH AND MITOTIC COUNT

Intestinal biopsies were stained by the modified Feulgen technique and microdissected using a cataract knife as previously described. ${ }^{13}$ These fragments were mounted in $45 \%$ acetic acid as a wet film on a slide and coverslipped. Using a calibrated microscopic graticule, the length (1), apical width (a), and maximal basal width (w) of eight to 15 villi and the length of 10 to 15 crypts were measured and the mean of each calculated (Fig 1). The apical width was measured $78.9 \mu \mathrm{m}$ (10/100 graticule units) from the apex that is, approximately at one-tenth of the length villus. The tissue was squashed and mitotic figures counted in ten to fifteen crypts.

Villus area was calculated using a geometric approximation of a small triangle mounted on a larger trapezoid, for which the major base was the maximal basal width (Fig 1). The surface area was computed by adding the area of this triangle and trapezoid. This method was simplified from a previous algorithm which also used a trapezoid approximation for calculating villus area, as described by Lorenz-Meyer, Köhn and Riecken. ${ }^{1+}$ Their alogrithm, which was validated planimetrically, calculates the surface area of both surfaces of the villus, whereas the present one calculates the surface area of one face. We have used data from another study by these authors in the rat, ${ }^{15}$ and shown a correlation $\left(r^{2}\right)$ of 0.95 by the two methods. Surface area was calculated using a computer program written for the Apple Macintosh computer. 
TABLE II Duodenal counts of mucosal mast cells, intraepithelial lymphocytes and goblet cells in subjects with asymptomatic HIV infection, AIDS/ARC, coeliac disease before treatment, and normal subjects

\begin{tabular}{llll}
\hline & $\begin{array}{l}\text { Mucosal mast } \\
\text { cells } \\
(/ \mathbf{m m})\end{array}$ & $\begin{array}{l}\text { Intraepithelial } \\
\text { lymphocytes } \\
(/ \mathrm{mm})\end{array}$ & $\begin{array}{l}\text { Goblet cells } \\
(/ \mathrm{mm})\end{array}$ \\
\hline Control $(\mathrm{n}=15)^{\star}$ & $36(15)$ & $47(21)$ & $70(17)$ \\
HIV $(\mathrm{n}=2)$ & $41(18)$ & $37(18)$ & $71(15)$ \\
AIDS/ARC $(\mathrm{n}=8)$ & $41(18)$ & $37(18)$ & $71(15)$ \\
Coeliac disease $(\mathrm{n}=3)$ & $44(12)$ & $55 \dagger$ & $51 \dagger$ \\
\hline
\end{tabular}

^ One biopsy from the control subjects was unsuitable for cell counts. tOne biopsy from coeliac subjects was unsuitable for intraepithelial lymphocyte and goblet cell

DUODENAL CELL COUNTS

Tissue fixed in Carnoy's fixative was embedded in paraffin according to conventional techniques and sections $(4 \mu \mathrm{m})$ cut. Intraepithelial lymphocyte and goblet cells were counted on sections stained with haematoxylin and eosin, and mucosal mast cells were counted in sections stained with Alcian blue ( $\mathrm{pH} \mathrm{0 \cdot 3)/safranin.} \mathrm{Cells}$ were counted above the muscularis mucosae using a linear graticule $(296 \mu \mathrm{m})$ and $25 \mathrm{x}$ objective lens. ${ }^{16}$ Four to 10 counts was obtained for each subject. Cell counts were expressed as cells $/ \mathrm{mm}$ of muscularis mucosae.

\section{STATISTICAL ANALYSIS}

Peritz' $F$ test was used to compare the group means of the morphological measures and duodenal cell counts. ${ }^{17}$ All results are expressed as the mean $(\mathrm{SD})$.

\section{Results}

\section{INTESTINAL MORPHOLOGY}

In patients with $\mathrm{HIV}$ infection, villus area was reduced by $27 \%(p<0.0001)$, crypt length was similar $(p=0 \cdot 28)$ but mitotic count of crypts was increased to $3 \cdot 7(p=0.01)$, when compared to biopsies from control subjects (Fig 2). The increase in mitotic count was relatively impaired as we would have expected a value of approximately 5.4 for this degree of villous atrophy. This expectation is based on a curvilinear relationship of villous atrophy to mitotic count in coeliac subjects (unpublished observation). Thus, there was villous atrophy with impaired crypt hyperplasia. The only patient with AIDS, who was not receiving zidovudine, had a villus area of $0.306 \mathrm{~mm}^{2}$, crypt length of $217 \mu \mathrm{m}$ and mitotic count of $2 \cdot 8$ - that is, similar to the mean values for the AIDS/ARC group. This would indicate that zidovudine was not the cause of the enteropathy. Untreated coeliac patients had a $64 \%$ reduction in villus area $(\mathrm{p}<0001)$, crypt length increased by $224 \%(\mathrm{p}<0.0001)$ and mitotic count was increased to $6.9(\mathrm{p}<0.0001)$, indicating villous atrophy with compensatory crypt hyperplasia.

\section{DUODENAL CELL COUNTS}

Satisfactory duodenal counts were done on biopsies of 15 of the 16 control, one of two HIV-infected subjects who were asymptomatic, and eight subjects with AIDS/ARC. Counts of mucosal mast cells, intraepithelial lymphocyte and goblet cells were similar in the HIV-infected subjects compared to those in control subjects (Table II). In coeliac subjects, mucosal mast cells were done in three subjects, and intraepithelial lymphocyte and goblet cell counts in two subjects. Coeliac subjects did not differ in counts of mucosal mast cells, intraepithelial lymphocyte or goblet cells, although the number of subjects was small.

\section{Discussion}

We have shown that enteropathy associated with HIV infection (resulting in AIDS or ARC) has villous atrophy but impaired crypt hyperplasia, and that duodenal counts of mucosal mast cells, intraepithelial lymphocyte and goblet cells were similar to normal subjects. This is an unusual pattern of enteropathy and suggests that villous atrophy in these patients was not mediated by mucosal $\mathrm{T}$ lymphocytes which are deficient in AIDS, ${ }^{18}$ even though these cells mediate villous atrophy experimentally in GvHR, which is the model of a $\mathrm{T}$ cell mediated response.

Villous atrophy could be mediated by direct viral infection of villous epithelial cells, or of supportive cells in the underlying lamina propria such as lymphocytes, macrophages or fibroblasts. Small virus-like particles have been seen by electron microscopy in intestinal or colonic epithelial cells and in histiocytes of the lamina propria in two of six AIDS subjects at autopsy, ${ }^{19}$ although another study failed to find virus particles in rectal biopsy material. ${ }^{20} \mathrm{HIV}$ has been detected by in situ hybridisation in the lamina propria of the duodenum, and in enterochromaffin cells and possibly other cells of rectal crypts. ${ }^{21}$ Two asymptomatic HIV-infected subjects, however, did not have villous atrophy which might indicate that HIV infection does not directly the villus, although this view would depend on the number and variety of cells infected at different clinical stages of the disease. Another suggested mechanism for villous atrophy is immune complex reaction which, together with $T$ cells may mediate villous atrophy in coeliac disease. ${ }^{22}$ AIDS is associated with hypergammaglobulinaemia, ${ }^{5}$ which potentially could react with gut luminal antigens to form such immune complexes. A further mechanism for villous atrophy is secondary to reduced mitotic activity of intestinal crypts that may or may not be associated with active destruction of villous epithelial or supportive cells in the lamina propria. It is unlikely that zidovudine treatment caused villous atrophy as the one AIDS subject, who was not receiving the drug, had villous atrophy.

Evidence suggests that the mitotic rate of intestinal crypts is regulated by the activity of mucosal $\mathrm{T}$ lymphocytes. This has been principally shown experimentally in rodents with possible involvement of $T$ cell activation with crypt hyperplasia at weaning, ${ }^{16}$ in mucosal GvHR, ${ }^{8923}$ and during immune expulsion of the Nippostrongylus - nematode from the small intestine. ${ }^{6}$ The principle of $T$ cell dependence of crypt hyperplasia has been confirmed in human gut using the technique of explant foetal culture; MacDonald and Spencer ${ }^{7}$ have shown that crypt 
hyperplasia in human fetal intestinal explant culture is induced by activation of $T$ cells with pokeweed mitogen or with anti-CD3 antibody, and conversely that cyclosporin A treatment inhibited crypt hyperplasia. Thus a variety of studies in rodents and man have demonstrated the $T$ cell dependence of intestinal crypt hyperplasia. The present findings of impaired intestinal crypt hyperplasia in the enteropathy of AIDS/ARC would be expected from the immunodeficiency of mucosal $T$ cells, and further supports the general notion that mucosal $T$ cells control the mitotic rate of intestinal crypts.

This impaired crypt hyperplasia should be regarded as relative because crypt length was similar to those of normal subjects rather than being hypoplastic. This could be because of the influence of residual T cells, or because of nonimmune factors also influencing the proliferation of intestinal crypts. The similarity in intestinal crypt length of HIV-infected and control subjects would indicate equivalent crypt cell population as crypt length and crypt cell count are directly correlated. The discrepancy between this and some (but impaired) increase to mitotic activity suggests that there was crypt cell destruction due to HIV infection, as otherwise crypt length would be increased in HIV subjects. This notion has some support by the finding of HIV infection in intestinal and rectal crypts in an in situ - hybridisation study. ${ }^{21}$ This would mean there is decreased crypt cell efflux onto villi of HIV-infected subjects from reduced mitotic rate as well as from destruction of crypt cells within the intestinal crypt.

The relative failure of crypt hyperplasia contrasts with the study by Kotler et al. ${ }^{5}$ which reported crypt hyperplasia in biopsies of small intestine from AIDS patients. Their study was based on subjective assessment without quantitative measures because of acknowledged difficulties with imperfect orientation of biopsies. The use of a microdissection technique in our study has overcome this problem. It is also possible that their study may have had individuals who were not as immunodeficient as those in our present study and whose biopsy might have therefore shown some measure of crypt hyperplasia. Batman et $a l^{24}$ also reported crypt hyperplastic villous atrophy in quantitative study of enteropathy of HIV infection. They measured the mucosal architecture index that is, the ratio of surface area to volume of lamina propria, and column count of the intestinal crypt. A lower architecture index confirmed villous atrophy in HIV subjects, particularly those with AIDS. The authors concluded that crypt length by column cell count in HIV subjects had a tendency to crypt hyperplasia, although their data overlapped with that of control subjects, as was the case for four of their AIDS individuals. No statistics were done to reach this conclusion for this particular measurement, and no comparison was made of crypt length in a disease group known to have crypt hyperplasia such as coeliac disease.

Irani et $a l^{12}$ found that mucosal mast cells (' $\mathrm{T}$ mast cell') in the ileum of three patients with AIDS were reduced to $5 \%$ of the number in normal ileam, and similarly that mucosal mast cells were reduced (to less than $1 \%$ ) in two patients with severe combined immunodeficiency syndrome. The majority of these specimens were taken at autopsy, and thus it is likely that these agonal patients were severely malnourished. This could be a confounding factor for the reduction of mucosal mast cell as malnutrition in the rat depletes mucosal mast cells, although, interestingly, it has less of an effect on functional mucosal mast cell activity. ${ }^{25}$ While mucosal mast cell hyperplasia is T cell dependent, ${ }^{26}$ nevertheless mucosal mast cells are not totally depleted in $\mathrm{T}$ cell immunodeficiency states. ${ }^{27}$ Although the patients in this present study were immuodeficient with low CD4 cells (Table I), the number of mucosal mast cells was similar to normal subjects. Bishop et al ${ }^{28}$ also found a similar number of mucosal mast cells in four jejunal biopsies of AIDS patients. At the present time, activity of human mucosal mast cells can only be measured in vivo by specific tryptase secretion which apparently is not sensitive at physiological levels. ${ }^{29}$ Studies in rodents examining systemic release of a soluble mucosal mast cell granule protein, rat mucosal mast cell protease 11 , have shown that a fall in mucosal mast cells may be associated with either decreased activity, ${ }^{9}$ or with increased activity. ${ }^{16}{ }^{30}$ Thus, it is not prudent to rely on mucosal mast cell count to infer mucosal mast cell activity.

Kotler et $a l^{5}$ reported that intraepithelial lymphocytes were increased in the enteropathy of AIDS when the count was expressed per 100 epithelial cells. Our present study showed that the IEL count was similar in control of AIDS subjects when expressed per mm of muscularis mucosae. One explanation may be that their AIDS patients were less immunodeficient and therefore showed a pattern of enteropathy similar to that seen in coeliac disease. The most likely explanation however, is the manner of expression of cell count. Both intraepithelial lymphocyte count $/ \mathrm{mm}$ and $/ \mathrm{mm}^{2}$ of muscularis mucosae are not affected by spurious increase in count due to decrease in volume of tissue with the only assumption being that the muscularis mucosae remains unaltered..$^{3132}$ Batman et $a l^{24}$ also found that the intraepithelial lymphocyte count was similar to that in control subjects when expressed per mm of muscularis mucosae. This preservation of intraepithelial lymphocytes indicate they are not directly affected by HIV infection and contrasts with immunodeficiency of other lymphocytes in the lamina propria and systemically. ${ }^{28}$ This may be because intraepithelial lymphocytes have the $\gamma \delta$ T-cell receptor (at least in the mouse) rather than the $\alpha \beta$ T-cell receptor of systemic lymphocytes, ${ }^{33}$ and therefore are a fundamentally different (possibly more primitive) population of immune cells.

The number of goblet cells showed no decrease as might be expected from their possible dependence on $\mathrm{T}$ cells. ${ }^{10}$ This presumably means that the number of goblet cells are influenced by other factors. Any inference of goblet cell function must, however, be cautious as the count may be underestimated because of mucus discharge and difficulty in counting goblet cells. 
In conclusion, our present study has shown an unusual pattern of enteropathy in AIDS/ARC with villous atrophy with impaired crypt hyperplasia but normal duodenal counts of mucosal mast cells, intraepithelial lymphocytes and goblet cells. The failure to compensate by crypt hyperplasia in the intestine of these subjects would severely compromise repair of villous atrophy and function of the gut. In addition, HIV infection may possibly destroy intestinal crypt cells and reduce available crypt cells to populate adjacent villi.

Dr Cummins was supported during this study by a Florey Research Fellowship from Royal Adelaide Hospital. We are grateful to Mrs J Langman for technical assistance. We thank Dr $\mathrm{D}$ Gillis for allowing us to study two of his patients and for reporting the flow cytometry (Division of Human Immunology, Institute of Medical and Veterinary Science).

1 Gillin JS, Shike M, Alcock N, et al. Malabsorption and mucosal abnormalities of the small intestine in the Acquired mucosal abnormalities of the small intestine in the Acquired
Immunodeficiency Syndrome. Ann Int Med 1985; 102: 619-22.

2 Colebunders R, Lusakumuni K, Nelson AM, et al. Persistent diarrhoea in Zairian AIDS patients: an endoscopic and histological study. Gut 1988; 29: 1687-91.

3 Malebranche R, Guerin JM, Laroche AC, et al. Acquired immunodeficiency syndrome with severe gastrointestinal tract manifestations in Haiti. Lancet 1983; ii: 873-7.

4 Anthony MA, Brandt LJ, Klein RS, Bernstein LH. Infectious diarrhea in patients with AIDS. Dig Dis Sci 1988; 33: 1141-6.

5 Kotler DP, Gaetz HP, Lange M, et al. Enteropathy associated with the acquired immunodeficiency syndrome. Ann Int Med 1984; 101: 421-8.

6 Ferguson A, Jarrett EE. Hypersensitivity reactions in the small intestine. I. Thymus dependency of experimental small intestine. I. Thymus dependency of

7 MacDonald TT, Spencer J. Evidence that activated mucosal T cells play a role in the pathogenesis of enteropathy in human small intestine. 7 Exp Med 1988; 167: 1341-9.

8 Mowat AMcI, Ferguson A. Intraepithelial lymphocyte count and crypt hyperplasia measure the mucosal component of the graft-versus-host reaction in mouse small intestine. Gastroenterology 1982; 83: 417-23.

9 Cummins AG, Munro GH, Miller HRP, Ferguson A. Separate effects of irradiation and graft-versus-host reaction on mucosal mast cells in the rat. Gut 1989; 30: 355-60.

10 Karlson G, Hansson H-A, Petruson B, Bjorkander J, Hanson LA. Goblet cell number in the nasal mucosa relates to cellmediated immunity in patients with antibody deficiency mediated immunity in patients with antibody deficiency

11 Miller HRP. Nawa Y. Nippostrongylus brasiliensis: Intestinal goblet cell response in adoptively immunized rats. Exp Parasitol 1979; $47: 81-90$.

12 Irani A-MA, Craig SS, DeBois G. Elson CO, Schechter NM, Schwartz LB. Deficiency of the tryptase-positive, chymasenegative mast cell type in gastrointestinal mucosa of patients with defective T lymphocyte function. F Immunol 1987; 138: 4381-6.

13 Ferguson A, Sutherland A. MacDonald TT, Allan F. Technique for microdissection and measurement in biopsies of human small intestine. $\mathcal{F}$ Clin Pathol 1977; 30: 1068-73.

14 Lorenz-Meyer H, Köhn R, Riecken EO. Vergleich vergschiedener morphometrischer methoden zur erfassung der schleimhautoberflache des rattendunndarms und deren beziehung zur funktion. Histochemistry 1976; 49: 123-9.

15 Menge H, Germer C-T, Strössel R, Simes G, Hahn H Riecken EO. Pathogenesis of the mucosal hyperplasia in self-filling blind loops of rat jejunum: a morphometric study in germ-free animals. Gut 1987; 28: 175-80 (Suppl).

16 Cummins AG, Steele TW, LaBrooy JT, Shearman DJC. Maturation of the rat small intestine at weaning: changes in epithelial cell kinetics, bacterial flora, and mucosal immun activity. Gut 1988; 29: 1672-9.

17 Harper JF, Peritz' F test: BASIC program of a robust multiple comparison test for statistical test of all differences amon group means. Comput Biol Med 1984; 14 : 437-45.

18 Rodgers VD, Fassett R, Kagnoff MF. Abnormalities in intestinal mucosal $\mathbf{T}$ cells in homosexual populations including those with the lymphadenopathy syndrome and acquired immunodeficiency syndrome. Gastroenterology acquired imm 1986 ; $552-8$.

19 Chandler FW, White EH, Callaway CS, Spira TJ, Ewing EP. Unidentified virus-like particles in the intestine of patients with the Acquired Immunodeficiency Syndrome. Ann Int Med 1984; 100: 851-3.

20 Kotler DP, Weaver SC, Terzakis JA. Ultrastructural features of epithelial cell degeneration in rectal crypts of patients with AIDS. Am $\mathcal{F}$ Surg Pathol 1986; 10: 531-8.

21 Nelson JA, Wiley CA, Reynolds-Kohler C, Reese C, Margaretten W, Levy JA. Human immunodeficiency virus detected in bowel epithelium from patients with gastrointestinal symptoms. Lancet 1988; i: 269-2.

22 Bramble MG, Zucoloto S, Wright NA, Record CO. Acute gluten challenge in treated adult coeliac disease: a morphogluten challenge in treated adult coeliac disease: a
metric and enzymatic study. Gut 1985; 26: 169-74.

23 MacDonald TT, Ferguson A. Hypersensitivity reactions in the small intestine. 3 . The effects of allograft rejection and of graft-versus-host reaction on epithelial cell kinetics. Cell Tissue Kinet 1977; 10: 301-12.

24 Batman PA, Miller ARO, Forster SM, Harris JRW, Pinching AJ, Griffin GE. Jejunal enteropathy associated with human immunodeficiency virus infection: quantitative histology. $\mathcal{F}$ Clin Pathol 1989; 42: 275-81.

25 Cummins AG, Kenny A, Duncombe VM, Bolin TD, Davis AE. The effect of protein deficiency on systemic release of rat mucosal mast cell protease II during Nippostrongylus brasiliensis infection and following systemic anaphylaxis. Immunol Cell Biol 1987; 65: 357-63.

26 Nawa Y, Miller HRP. Adoptive transfer of the intestinal mast cell response in rats infected with Nippostrongylus brasiliensis. Cell Immunol 1979; 42: 225-39.

27 Mayrhofer G, Bazin H., Nature of the thymus dependency of mucosal mast cells. III. Mucosal mast cells in nude mice and nude rats, in B rats and in a child with the Di George Syndrome. Int Arch Allergy Appl Immunol 1981; 64: 320-31.

28 Bishop PE, McMillan A, Gilmour HM. Immunological study of the rectal mucosa of men with and without human immunodeficiency virus infection. Gut 1987;86: 139-42.

29 Wenzel S, Irani A-M, Sanders JM, Bradford TR, Schwartz LB. Immunosassay of tryptase from human mast cells. f Immunol Meth 1986; 86: 139-42.

30 Cummins AG, Munro GH, Miller HRP, Ferguson A. Effect of cyclosporin A treatment on the enteropathy of graftof cyclosporin A treatment on the enteropathy of graftintestinal morphology, epithelial cell kinetics and mucosal immune activity. Immunol Cell Biol 1989; 67: 153-60.

31 Guix M, Skinner JM, Whitehead R. Measuring intraepithelial lymphocytes, surface area, and volume of lamina propria in the jejunal mucosa of coeliac patients. Gut 1979; 20: $275-8$.

32 Marsh MN. Studies of intestinal lymphoid tissue. XI - The immunopathology of cell-mediated reactions in gluten sensitivity and other enteropathies. Scanning Microsc 1988; 2: 1663-84.

33 Goodman T, Lefrançois L. Expression of the $\gamma \delta \mathrm{T}$ cell receptor of intestinal CD8 + intraepithelial lymphocytes. Nature 1988; 333: 855-8. 